\title{
A study on prevalence and correlates of functional disability among the elderly in rural Tamilnadu
}

\author{
KR Sowmiya ${ }^{1}$, P. Ganesh Kumar ${ }^{2}$ Nagarani $^{3}$ \\ ${ }^{1}$ Dr.KR.Sowmiya, Assistant Professor, Department of Community Medicine, Tagore Medical College and Hospital, \\ Rathinamangalam, Vandalur Post, Chennai, Tamilnadu, ${ }^{2}$ Dr.P.Ganesh Kumar, Scientist at National Institute of \\ Epidemiology, Chennai, ${ }^{3}$ Dr. Nagarani, Associate Professor Thiruvanamalai Medical College, Thiruvanamalai
}

Address for Correspondence: Dr.KR.Sowmiya, Email: dr_sowmiya_kr@yahoo.co.in

\begin{abstract}
Introduction: Functional status assessment is fundamental to geriatric care. Hence this study was done to know the prevalence of functional disability among the elderly aged 60 years and above residing in a rural area of Tamilnadu and to identify the socio demographic and health correlates that influence their functional status. Methodology: This cross sectional study was done among elderly members residing in a rural part of Tamilnadu. Functional status of the study population vision, hearing, arm function, leg function, cognition and Activities of Daily Living (ADL) were assessed. Results: The prevalence of functional disability among the elderly aged 60 years and above was found to be $46.84 \%$.Visual impairment was the most commonly observed functional defect with $34 \%$ of female and $21.6 \%$ of male elderly being affected. $27.3 \%$ of female elders were dependent for doing their Activities of Daily Living. Hearing impairment was also common with $16.4 \%$ and $28.7 \%$ of male and female elders being affected respectively. The prevalence of functional disability was very high with advancing age, presence of co morbidities, illiteracy and economical dependence. The prevalence of functional disability was low among the male elderly and those who lived with their spouse and children. Conclusion: This study emphasizes the need for assessing the functional status of the elderly population at primary health care level to determine their needs, develop interventions to restore or maintain function or prevent or minimize its decline, and prevent secondary disabilities.
\end{abstract}

Key words: Functional disability, elderly, Activities of Daily Living.

\section{Introduction}

Ageing is a normal, inevitable, biological and universal phenomenon. It is the outcome of certain structural and functional changes taking place in different parts of the body as the age progresses. In the year 2002, there were an estimated 605 million old persons in the world, of which 400 million were living in low-income countries [1]. India caters the second largest elderly population in the world and it is estimated that the proportion of elderly people will increase from $8 \%$ in 2010 to about $19 \%$ in 2050 [2]. With this demographic trend the current health system have to deal with the health challenges of the elderly who may be prone to chronic diseases. As disabilities are common complication of chronic diseases, understanding their functional status is vital to curtail this health issue. Hence under these circumstances, assessment of the functional status of the geriatric population is of prime importance and basic entity of the health system. Using functional status information, health care providers can help their patients maximize their

Manuscript received: $17^{\text {th }}$ Apr 2015

Reviewed: $22^{\text {th }}$ Apr 2015

Author Corrected: $13^{\text {th }}$ May 2015

Accepted for Publication: $31^{\text {st }}$ May 2015 abilities, thus providing the best of health care to them. Studies on functional status of the elderly and their disabilities are found to be few in the existing literature. Therefore this study is intended to assess the functional status of the elderly aged 60 yrs and above and the factors influencing their functional capacity.

\section{Methodology}

This cross sectional study was conducted in from April 2010 to October 2010 at a rural area, Mettupalayam which is under the Thiruvallur district of Tamilnadu. The approval of the Institutional ethics committee was taken for carrying out this study. This rural area was selected by simple random sampling method out of the 7 rural areas of Minjur and Ponneri Primary Healthcare Centres. As per their sub centre records the total population of Mettupalayam was 6041 and the total number of the elderly were 509. Functional status was assessed for all the elderly in that area. Home visits were made to contact the elderly and if found missing subsequent visits will be made to complete the study. Only those who gave informed consent were included in the study. 
Study instrument contained the following:

1. Lachs instrument was used to assess vision, hearing, locomotor ability- arm function, leg function [3].

2. Elderly cognition assessment questionnaire was used to assess the cognition of the elderly [4].

3. Katz scale was used to assess the activities of daily living (ADL) in the elderly [5].

4. Socio demographic profile of the study population such as age, sex, education, marital status, living arrangements, economic dependency, monthly income of the family as well as the personal income, etc.

5. Self reported co morbid conditions.

\section{Methods for functional status assessment:}

Vision was tested by finger counting (vision-with or without spectacles depending on whether the individuals were using spectacles or not) at a distance of 3 meters for each eye separately in good daylight. The person's vision was recorded as 'able to count' or 'unable to count' at this distance (i.e. vision $\geq 3 / 60$ or worse than that) $[3,4]$.

For assessing hearing, simple questions (e.g. what is your name? or where do you live?) was whispered from behind the head. To check for their hearing, the investigator stood 12 to 24 inches behind the patient, covered one ear, and whispered the words in the uncovered ear, which were repeated by the patient. The person's hearing was recorded as 'able to hear' or 'unable to hear' [3, 4].

Arm function: Proximal function was assessed by ability of the participants to touch the back of the head and the distal function was assessed by asking the respondent to pick up a pen. A study subject was designated as having abnormal results in case of inability to do the task [3, 4].

Leg function: The respondent was asked to rise from the cot/chair, walk a distance of 10 feet, return and sit down. Inability to walk or transfer out of cot/chair was designated as abnormal result $[3,4]$.

Using the elderly cognitive assessment questionnaire their cognition was assessed. There were a total of ten questions out of which a score of less than 6 is designated as cognitive defect [4].
Activities of daily living (ADL) referred to such daily routine activities as below: Bathing, Dressing, Toileting, Transferring (from chair to bed and vice versa), Continence and Feeding. And their independence in activities of daily living was assessed using Katz scale. It is a two point scale where one point is given for elderly who does all the above said activities with no supervision, or personal assistance and zero point if it is done with supervision, direction, personal assistance or total care. The elderly will be termed independent in ADL if the total score is six or else he/she is termed as ADL disabled $[5]$.

Functional disability was defined as having disability in Activities of daily living (ADL), visual impairment, hearing impairment, locomotor defects (arm and leg function), defect in cognition, or a combination of these .

\section{Data Analysis:}

The information thus collected by the questionnaire, was tabulated and analysed in SPSS 13.0 Software. The prevalence of functional disability was estimated and expressed in percentage with $95 \%$ confidence interval [CI]. Adjusted Odds ratios were estimated by logistic regression analysis to identify the factors influencing the functional status. $\mathrm{P}<0.05$ was considered to be statistically significant.

\section{Results}

Only 476 elderly were included in the study out of the 509 individuals, with $6.2 \%$ as non response rate due to various reasons. Out of the 476 elderly individuals included in the study, 282(59.2\%) were females and 194 (40.8\%) males (Table1). The mean age of the study population was 68.32 \pm 7.35 years. Majority of the elderly were illiterate $(65.5 \%)$, and more than $80 \%$ of the elderly population were living either with their spouse or children and $60 \%$ of the elderly were economically independent (Table1). $18 \%$ of the elderly individuals did not have any source of income and were below the poverty line. Only $19 \%$ of them received old age pension (Table1). The most prevalent self reported illness was arthritis followed by Type II diabetes mellitus and hypertension (Table 2). 
Table 1 Socio demographic characteristics of the study population

\begin{tabular}{|c|c|c|}
\hline Characteristics & $\begin{array}{l}\text { Male }(\%) \\
n=194\end{array}$ & $\begin{array}{l}\text { Female }(\%) \\
n=282\end{array}$ \\
\hline $\begin{array}{l}\text { Age } \\
60-69 y r s \\
70-79 y r s \\
\geq 80 y r s\end{array}$ & $\begin{array}{l}122(62.9) \\
63(32.5) \\
9(4.6)\end{array}$ & $\begin{array}{l}153(54.3) \\
96(34) \\
33(11.7)\end{array}$ \\
\hline $\begin{array}{l}\text { Education } \\
\text { Illiterate } \\
\text { Primary schooling } \\
\text { Middle schooling } \\
\text { Higher schooling } \\
\end{array}$ & $\begin{array}{l}99(51.1) \\
45(23.2) \\
22(11.3) \\
28(14.4)\end{array}$ & $\begin{array}{l}213(75.5) \\
38(13.5) \\
25(8.9) \\
6(2.1) \\
\end{array}$ \\
\hline $\begin{array}{l}\text { Living arrangements } \\
\text { Living alone } \\
\text { Living with spouse } \\
\text { Living with spouse and children } \\
\text { Living with children } \\
\text { Others }\end{array}$ & $\begin{array}{l}30(15.5) \\
55(28.4) \\
92(47.4) \\
15(7.7) \\
2(1.0)\end{array}$ & $\begin{array}{l}46(16.3) \\
55(19.5) \\
67(23.8) \\
106(37.6) \\
8(2.8)\end{array}$ \\
\hline $\begin{array}{l}\text { Economic dependency } \\
\text { Independent } \\
\text { Dependent }\end{array}$ & $\begin{array}{l}158(81.4) \\
36(18.6)\end{array}$ & $\begin{array}{l}126(44.7) \\
156(55.3)\end{array}$ \\
\hline $\begin{array}{l}\text { Marital status } \\
\text { Never married } \\
\text { Married } \\
\text { Widow/ widower } \\
\text { Separated }\end{array}$ & $\begin{array}{l}6(3.1) \\
147(75.8) \\
41(21.1) \\
0\end{array}$ & $\begin{array}{l}0 \\
124(44) \\
157(55.7) \\
1(0.4)\end{array}$ \\
\hline $\begin{array}{l}\text { Source of income } \\
\text { Service pension } \\
\text { Family pension } \\
\text { Old age pension } \\
\text { Agriculture } \\
\text { Business } \\
\text { Wages } \\
\text { No income }\end{array}$ & $\begin{array}{l}33(17) \\
0 \\
20(10.3) \\
43(22.1) \\
34(17.5) \\
61(31.5) \\
3(1.5)\end{array}$ & $\begin{array}{l}12(4.2) \\
9(3.2) \\
72(25.5) \\
6(2.1) \\
9(3.2) \\
93(32.9) \\
81(28.7)\end{array}$ \\
\hline
\end{tabular}

Table 2: Self reported morbidity profile of the study population

\begin{tabular}{|l|l|l|}
\hline Morbidity & $\begin{array}{l}\text { Male (\%) } \\
\mathbf{n = 1 9 4}\end{array}$ & $\begin{array}{l}\text { Female (\%) } \\
\mathbf{n = 2 8 2}\end{array}$ \\
\hline Hypertension & $45(23.2)$ & $65(23.1)$ \\
\hline Type II diabetes mellitus & $69(35.5)$ & $114(40.4)$ \\
\hline Arthritis & $75(38.6)$ & $206(73.1)$ \\
\hline Cardio vascular diseases & $23(11.8)$ & $30(10.6)$ \\
\hline Gastrointestinal diseases & $14(7.2)$ & $31(10.9)$ \\
\hline Pulmonary diseases & $32(16.5)$ & $15(5.3)$ \\
\hline Skin disorders & $3(1.5)$ & $10(3.5)$ \\
\hline Injury & $6(3.1)$ & 0 \\
\hline Cancer & $3(1.5)$ & 0 \\
\hline Genito-urinary diseases & 0 & $1(0.3)$ \\
\hline Anemia & $3(1.5)$ & $3(1.1)$ \\
\hline Others & $5(2.5)$ & $10(3.5)$ \\
\hline
\end{tabular}




\section{Research Article}

The prevalence of functional disability among the elderly aged 60years and above was $46.84 \%$. "Functional disability among females $(56.7 \%)$ was found to be more than compared to males $(32.5 \%)$ in the study population (Figure 1$)$.

Figure 1: Sex distribution of Functional disability

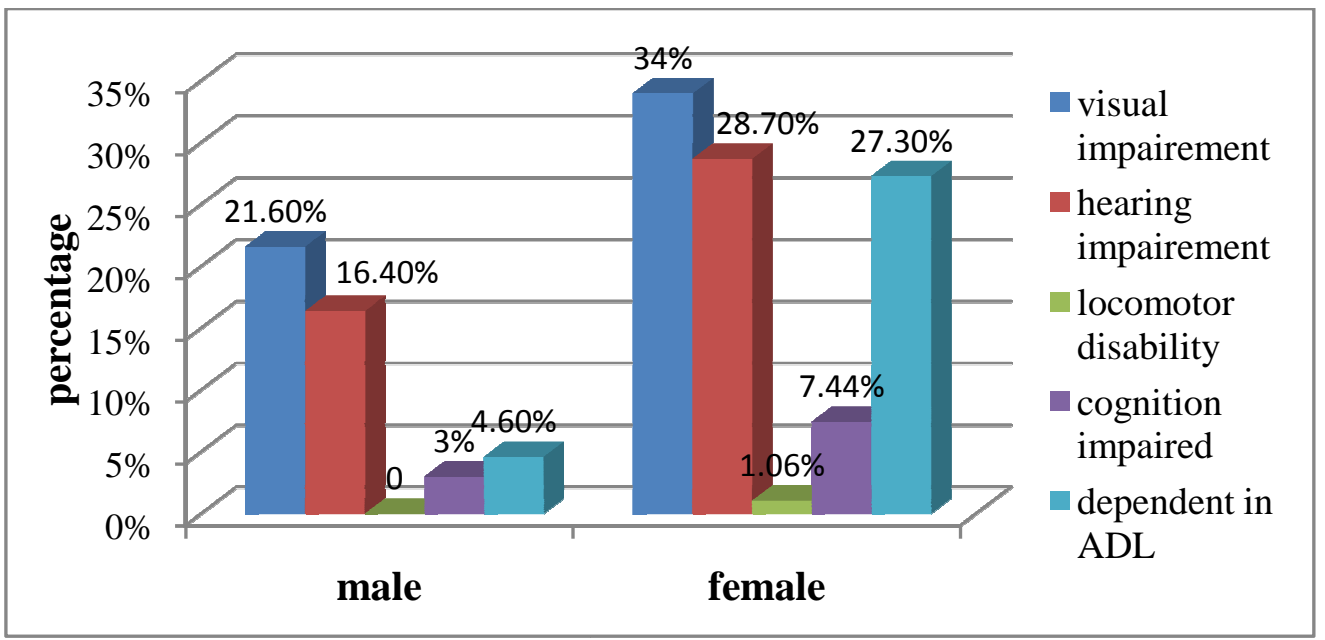

The prevalence of functional disability was high among the oldest of old people aged more than or equal to 80 years (odds ratio 3.06; 95\% CI 1.44-6.48) (Table 3). Significant association was seen with elderly who reported co morbidities, who were illiterate and economically dependent on others (Table 3). The prevalence of functional disability was low among the male elderly and those who lived with their spouse and children (Table 3).

Table 3: Determinants of Functional disability by logistic regression

\begin{tabular}{|c|c|c|c|c|c|c|}
\hline $\begin{array}{l}\text { Socio demographic } \\
\text { variables }\end{array}$ & $\mathbf{n}$ & $\begin{array}{l}\text { Prevalence } \\
\text { of functional } \\
\text { disability } \\
(\%)\end{array}$ & $\begin{array}{l}\text { Unadjusted } \\
\text { odds ratio } \\
(95 \% \mathrm{CI})\end{array}$ & $\begin{array}{l}\mathbf{P} \\
\text { value }\end{array}$ & $\begin{array}{l}\text { Adjusted odds } \\
\text { ratio }(95 \% \mathrm{CI})\end{array}$ & $P$ value \\
\hline $\begin{array}{l}\text { Age } \\
60-69 \mathrm{yrs}^{*} \\
70-79 \mathrm{yrs} \\
\geq 80 \mathrm{yrs}\end{array}$ & $\begin{array}{l}275 \\
159 \\
42\end{array}$ & $\begin{array}{l}23.6 \% \\
57.1 \\
84.3\end{array}$ & $\begin{array}{l}1 \\
1.23(0.11-0.45) \\
4.02(1.9-8.4)\end{array}$ & $\begin{array}{l}- \\
0.00^{\dagger} \\
0.00^{\dagger}\end{array}$ & $\begin{array}{l}1 \\
1.48(1.16-3.4) \\
3.06(1.44-6.48)\end{array}$ & $\begin{array}{l}- \\
0.03^{\dagger} \\
0.02^{\dagger}\end{array}$ \\
\hline $\begin{array}{l}\text { Sex } \\
\text { Male* } \\
\text { Female }\end{array}$ & $\begin{array}{l}194 \\
282\end{array}$ & $\begin{array}{l}32.5 \\
56.7\end{array}$ & $\begin{array}{l}1 \\
1.36(1.12-2.53)\end{array}$ & $0.00^{\dagger}$ & $\begin{array}{l}1 \\
2.55(1.45-4.48)\end{array}$ & $-0^{-}$ \\
\hline $\begin{array}{l}\text { Literacy } \\
\text { Literate }^{*} \\
\text { Illiterate }\end{array}$ & $\begin{array}{l}164 \\
312\end{array}$ & $\begin{array}{l}22.0 \\
59.9\end{array}$ & $\begin{array}{l}1 \\
5.3(3.4-8.2)\end{array}$ & $0.00^{\dagger}$ & $\begin{array}{l}1 \\
2.1(1.4-4.2)\end{array}$ & $0.00^{\dagger}$ \\
\hline $\begin{array}{l}\text { Economic dependence } \\
\text { Independent } \\
{ }^{*} \\
\text { Dependent }\end{array}$ & $\begin{array}{l}284 \\
192 \\
\end{array}$ & $\begin{array}{l}38.4 \\
59.4\end{array}$ & $\begin{array}{l}1 \\
2.4(1.29-4.62)\end{array}$ & $-0^{-}$ & $\begin{array}{l}1 \\
2.14(1.18-3.89)\end{array}$ & $0.01^{\dagger}$ \\
\hline $\begin{array}{l}\text { Income } \\
\text { Has source of income* } \\
\text { No source of income }\end{array}$ & $\begin{array}{l}392 \\
84\end{array}$ & $\begin{array}{l}44.6 \\
57.1\end{array}$ & $\begin{array}{l}1 \\
2.6(1.37-3.97)\end{array}$ & $\begin{array}{l}- \\
0.03^{\dagger}\end{array}$ & $\begin{array}{l}1 \\
1.6(0.9-3.1)\end{array}$ & 0.33 \\
\hline $\begin{array}{l}\text { Living arrangements } \\
\text { Alone } \\
\text { With spouse } \\
\text { With spouse and children } \\
\text { With children } \\
\text { Others }\end{array}$ & $\begin{array}{l}76 \\
110 \\
159 \\
121 \\
10\end{array}$ & $\begin{array}{l}61.8 \\
37.3 \\
27.7 \\
42.7 \\
30.0\end{array}$ & $\begin{array}{l}6.2(1.51-25.4) \\
0.89(.22-3.6) \\
0.31(.1-2.6) \\
0.93(.35-2.5) \\
1\end{array}$ & $\begin{array}{l}0.6 \\
0.6 \\
0.03^{\dagger} \\
0.1 \\
-\end{array}$ & $\begin{array}{l}- \\
- \\
- \\
-\end{array}$ & $\begin{array}{l}- \\
- \\
- \\
- \\
-\end{array}$ \\
\hline $\begin{array}{l}\text { Co morbidity } \\
\text { Absent }{ }^{*} \\
\text { Present }\end{array}$ & $\begin{array}{l}45 \\
431\end{array}$ & $\begin{array}{l}20.0 \\
49.7\end{array}$ & $\begin{array}{l}1 \\
3.9(1.85-8.38)\end{array}$ & $-0^{-}$ & $\begin{array}{l}1 \\
1.84(1.02-2.5)\end{array}$ & $0.02^{\dagger}$ \\
\hline
\end{tabular}

* Reference for OR. ${ }^{\dagger} \mathrm{P}$ value 0.05 is considered as significant 


\section{Research Article}

\section{Discussion}

This study describes the epidemiology of functional disability among elderly persons in a rural area and its association with socio-demographic variables and selfreported chronic morbidity. The study population were elderly people aged 60 years and above residing in a rural area of Tamilnadu. Functional disability was defined as having disability in Activities of daily living (ADL), visual impairment, hearing impairment, locomotor defects (arm and leg function), defect in cognition, or a combination of these. The prevalence of functional disability among the elderly aged 60years and above was estimated to be $46.84 \%$. It is higher than the World health organisation and India Census estimates. World health organisation estimates that $15 \%$ of the world's population has some form of disability [6]. In India, the latest Census figures on disabilities have shown 26.8 million people are disabled (2.13\%) [7]. Disability prevalence rates in this study appear higher than in other developing countries. The prevalence of disability among the elderly in Malaysia, Srilanka and Nigeria was 9.5\% [8], 10\% [9], and $12.1 \%$ [10] respectively. However our results are consistent with the community-based study from rural Ballabhgarh, Northern part of India wherein the prevalence of functional disability was estimated to be 47.8\% [11]. Advancing age was significantly associated with functional disability as seen in most of the other studies conducted in India [12,13].

In the present study the disability prevalence was higher among the females when compared to the males in the same age group. This finding is comparable to the other studies conducted in Sweden [14] and Japan [15]. The possible explanation could be that musculoskeletal disease may have a greater influence on functional limitations in women than in men as seen in the population-based study in the United States which indicated that musculoskeletal impairments were attributed to disability more frequently in women than in men [16]. In our study, most of the disabled women suffered from musculoskeletal problems like arthritis and arthralgia.

Lack of literacy and having self reported co morbidities were also significantly associated with functional disability in our study. These findings are consistent with the findings of other population based studies where it was evident that prevalence of disability increased with co existing illness $[17,18,19]$.

The prevalence of functional disability was found to be low among those elderly who lived with their spouse and children when compared to those living alone or with their other relatives. This could be due to the fact that informal care to the elderly by their family members is always very supportive both physically and mentally to the old people. This finding is also observed in the community based studies conducted at Ireland [19] and China [20,21].

\section{Conclusion}

This study shows that the prevalence of functional disability is high among the rural elderly of Tamilnadu. A model of care providing comprehensive health services to elderly at all levels of health care delivery is imperative to meet this important health problem. Efforts should be made to strengthen the family system so that it continues to play the role of primary caregiver and financial security to the elderly, which will enable them to manage their health care needs. And most importantly the health care system has to be sensitised adequately to the health needs of the elderly. This can be achieved only by including geriatrics and gerontology in the undergraduate medical curriculum. The above addressed health problem can be addressed by the National Program for the Health Care for the Elderly which was recently launched in India. This program is an important milestone in elder's care as the program envisages dedicated health care facilities for the elderly and with provision for long term and short term training of health professionals to address the elder's health care needs. If properly implemented, this program can pave way for the 'healthy ageing' of our elderly population.

\section{Limitations}

This study is limited by involving only elderly people in rural community, excluding elders from institutions and those residing in urban areas. In addition, the study design does not also include information on duration of disability thus making it difficult to confirm the transient nature of the disabilities.

Funding: Nil, Conflict of interest: None initiated. Permission from IRB: Yes

\section{References}

1. Health action. Eldercare. $2004 \mathrm{Feb} ; 17(2): 2$.

2. Park K. Preventive Medicine in Obstetrics, Paediatrics and Geriatrics. In: Park K, editor. Park's Textbook of Preventive and Social Medicine. $23^{\text {rd }}$ edn. Jabalpur: M/s Banarsidas Bhanot 2015; 594-596

3. Lachs MS, Reinstein AR, Cooney LM et al. 1990. A simple procedure for general screening for functional 


\section{Research Article}

disability in elderly. Ann Intern Med. 1990 May 1;112(9):699-706.

4. Dr. Vinodkumar. Care of the elderly. A Training Manual for Multipurpose Workers and Medical Officers of Primary Health Care System in India 1996. 11-44

5. Katz S., Down, TD, Cash, HR, et al. (1970) Progress in the development of the index of ADL. Gerontologist. 1970 Spring;10(1):20-30..

6. World health organization. World report on disability. WHO: Geneva: 2011. Available from: http://www.who.int/disabilities/world_report/2011/report. pdf. [Last accessed on 2015 March 6]

7. Census of India 2001 and 2001. C series, Table C-20. Office of the Registar General of India. Available from: http://www/censusindia.gov.in/Tables_Published/C-

series/c_series_tables_2001. [last accessed on March $22^{\text {nd }}$ 2015]

8. Hairi et al. Prevalence and correlates of physical disability and functional limitation among community dwelling older people in rural Malaysia, a middle income country. BMC Public Health. 2010 Aug 18;10:492. doi: 10.1186/1471-2458-10-492.

9. Nugegoda DB, Balasuriya S: Health and social status of an elderly urban population in Sri Lanka. Social Science \& Medicine 1995, 40(4):437-442.

10. Abdulraheem I.S, Oladipo AR, and Amodu MO. Prevalence and Correlates of Physical Disability and Functional Limitation among Elderly Rural Population in Nigeria. Journal of Aging Research, vol. 2011, Article ID 369894, 13 pages, 2011. doi:10.4061/2011/369894

11. Goswami A, Reddiah VP, Kapoor SK, Singh B, Singh $\mathrm{U}$, Dey $\mathrm{AB}$, et al. Prevalence and determinants of disability in the rural elderly population in Northern India. Indian J Phys Med Rehabil 2005;16:39-44.

12. Ganesh K.S, Das A, Shashi JS. Epidemiology of Disability in a Rural Community of Karnataka. Indian $\mathbf{J}$ Public Health. 2008 Jul-Sep;52(3):125-9.
13. Gupta P, Mani K, Rai SK, Nongkynrih B, Gupta SK. Functional disability among elderly persons in a rural area of Haryana. Indian J Public Health 2014; 58:11-6

14. Von Strauss E, Agüero-Torres H, Kåreholt I, Winblad B, Fratiglioni L. Women are more disabled in basic activities of daily living than men only in very advanced ages: a study on disability, morbidity, and mortality from the Kungsholmen Project. J Clin Epidemiol. 2003 Jul;56(7):669-77.

15. Demura S, Sato S, Minami M, Kasuga K Gender and age differences in basic ADL ability on the elderly: comparison between the independent and the dependent elderly J Physiol Anthropol Appl Human Sci. 2003 Jan;22(1):19-27.

16. Wray LA, Blaum CS Explaining the role of sex on disability: a population-based study Gerontologist. 2001 Aug;41(4):499-510.doi: 10.1093/geront/41.4.499

17. Tas U, Verhagen A, Bierma-Zeinstra S, Hofman A, Odding E, Pols H, Koes B. Incidence and risk factor of disability in the elderly: the Rotterdam Study. Prev Med. 2007;44(3):272-278. doi: 10.1016/j.ypmed.2006.11.007.

18. Hairi, Noran $\mathrm{N}$ et al. Prevalence and Correlates of Physical Disability and Functional Limitation among Community Dwelling Older People in Rural Malaysia, a Middle Income Country. BMC Public Health 10 (2010): 492. PMC. Web. 8 May 2015.

19. Melzer D, Gardener E, Guralnik JM. Mobility disability in the middle-aged: cross-sectional associations in the English Longitudinal Study of Ageing. Age Ageing. 2005; 34(6):594-602. doi: 10.1093/ageing/afi188.

20. Zhu, Haiyan. Unmet Needs in Long-Term Care and Their Associated Factors among the Oldest Old in China. BMC Geriatrics 15 (2015): 46. PMC. Web. 6 May 2015.

21. Li M et al. rural urban differences in the long term care of the disabled elderly in china. PLoS ONE 8(11): e79955.doi:10.1371/journal.pone.0079955.

\section{How to cite this article?}

KR Sowmiya, P. Ganesh Kumar, Nagarani. A study on prevalence and correlates of functional disability among the elderly in rural Tamilnadu. Int J Med Res Rev 2015;3(4):430-435. doi: 10.17511/ijmrr.2015.i4.086. 